\title{
HIV 陽性入院症例の臨床的病理学的検討
}

\author{
横浜市立大学医学部第 1 内科 \\ 藤田 浩之 曽我 隆義 鈴木 淳一 \\ 石ケ坪良明毛利 博 大久保隆男 \\ 同 第 2 病理
}

長嶋洋治 三杉和 章

(平成 6 年 5 月 25 日受付)

(平成 7 年 1 月 10 日受理)

\section{Key words: AIDS, opportunistic infection, Condyloma acuminatum,}

Molluscum contagiosum, autopsy

\begin{abstract}
要旨
横浜市立大学医学部第 1 内科に入院した HIV 陽性患者について, 臨床的病理学的検討を加えたので 報告する. 対象は, 1988年 2 月より 1994年 5 月までの約 6 年間に, 当科に入院した HIV 陽性患者 13 例で, 外国人の 1 例を含め, 全例が男性であり, 初回入院時の年齢は, $18 \sim 70$ 歳であった. 感染経路は, 血液 製剤輸注 8 例, 性交渉 5 例で, 現在までに11例が AIDS を発症しており, 内 6 例が死亡している. 発症 原因は, カリニ肺炎, HIV 脳症などで, 発症時の CD4陽性リンパ球数は $3.4 \sim 220 / \mu 1$ (平均 $73 / \mu 1$ )であっ た. 延べ25回の入院理由は, 日和見感染が19回で, その内 6 回をカリ二肺炎が占めるが, 最近では予防 を行っているため減少している. 剖検は 4 例で施行された. 死亡時の CD4陽性リンパ球数は平均 $6.1 / \mu 1$ であり, 高度に細胞性免疫が低下した状態であった. 脳では, 脳の萎縮や, HIV 脳症の特徵的所見であ るグリア結節の形成がみられ，皮膚では，パピローマウイルスによる尖圭コンジローマや，ポックスウ イルスによる伝染性軟属腫がみられた。また全例でサイトメガロウイルス感染を示す封入体が認められ た. AIDS 発症からの生存期間は 5 力月から 42 力月で, $50 \%$ 生存期間は 26 月であった. 現在 AIDS は予 後不良の疾患群であるが, その生存日数は延長の方向にあり, すべての医療従事者は AIDS に対して, より積極的な対応を求められている.
\end{abstract}

\section{序文}

後天性免疫不全症候群 (Acquired immunodeficiency syndrome, AIDS) は，ヒト免疫不全 ウイルス (Human immunodeficiency virus, HIV）の感染により起こる細胞性免疫不全が本態

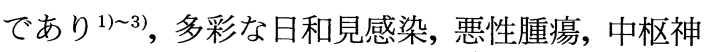
経症状を伴い, 致命的な経過をとる極めて予後不 良の疾患群である。

わが国では，1985年に AIDS 患者が初めて報告

別刷請求先：（テ241）横浜市旭区中尾町54-2 神奈川県立がんセンター血液科

藤田 浩之
されて以来, HIV 感染者数は徐々に増加し, 1994 年 4 月末までに厚生省に把握されている感染者数 は 3,000 人を越え, 実感染者数はその約 9 倍と推計 されている ${ }^{4) 5}$. しかし, 罹患すれば致命的であり, 性行為感染症であるといった疾患の特殊性から, 社会的偏見, 差別には根強いものがあり, 日本で の診療体制はまだ十分に確立されていないのが現 状である.そのため, AIDS 診療を行っていること が知られている病院以外からの報告はなく, 日本 人における AIDS 症例の臨床像について検討し た報告は非常に少ない。

当科では, 昭和 63 年以来 HIV 陽性患者の入院 
治療を行っており, 今回当科における HIV 陽性 入院患者について, 臨床病理学的に検討したので 報告する，なお本文に述べる AIDS とは，厚生省 AIDS サーベイランス委員会で採用されている AIDS 診断基準6を用い，診断したものである.

\section{対象および方法}

対象は,横浜市立大学医学部第 1 内科において, 1988年 2 月より1994年 5 月までの約 6 年間に入院 した HIV 陽性患者13例 (全例男性) である。この うち AIDS 発症と診断した11例については, AIDS 診断の根拠, 発症時の白血球数, CD4陽性り ンパ球絶対数, $\mathrm{CD} 4 / 8$ 比, 発症からの生存期間を検 討し, 延べ25回の入院については, その入院理由 および平均在院日数を調べ, 死亡例 6 例のうち剖 検の行われた 4 例については, その剖検所見につ いて，それぞれ検討した。

\section{成 績}

1) 患者背景 (Table 1)

対象症例は全例が男性で, 日本人 12 例, 外国人 1例（日系ブラジル人；症例10）であった。初回

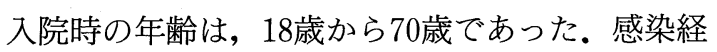
路は, HIV 污染血液製剤輸注 8 例, 異性間性交渉 2 例, 同性間性交涉 2 例, 両性間性交涉 1 例であっ た. 経過中に急性胃粘膜病変からの吐血により入 院した 1 例と, 帯状疱疹ウイルスによる䯣膜炎の ために入院した 1 例を除く11例が, AIDS を発症 しており，そのうち 6 例が死亡している。
2) AIDS 発症例の診断の根拠 と発症時の検査 所見 (Table 1)

AIDS 診断根拠の内訳は，カリニ肺炎が 5 例と 最も多く, 以下 HIV 脳症が 2 例, HIV 消耗症候 群, 悪性リンパ腫, クリプトコッカス髄膜炎, サ イトメガロウイルス網膜炎が各 1 例であった。し かし1991年以降，外来でペンタミジンの定期的吸 入および ST 合剤の予防的投与を行い，カリ二肺 炎の発症は 1 例のみと減少している。この症例は 発症前にカリ二肺炎の予防は行っていなかった。

発症時の CD4陽性リンパ球の絶対数は, $3.4 \sim 220 / \mu 1$ (平均 $73 / \mu 1$ ), また CD $4 / 8$ 比は $0.02 \sim 0.57$ (平均0.18) といずれも非常に低下し, 著しい細胞性免疫能の低下を示していた。CD4陽 性リンパ球数が $200 / \mu 1$ 以上で発症した例はわず かに 1 例のみで, 錯乱状態で入院した HIV 脳症 の症例であった。

AIDS 発症からの生存期間を Kaplan-Meier 法 で検討すると， 5 力月から 3 年以上で， $50 \%$ 生存 期間は26力月であった (Fig. 1)。また，発症後 3 年以上生存した例は 2 例と少なかった。

3）HIV 陽性患者の入院理由

延べ25回の入院について検討した。 入院理由と しては, 日和見感染が19回, HIV 脳症が 3 回，そ の他 3 回であった。日和見感染19回の内訳は，力 リ二肺炎が 6 回, 帯状疱疹ウイルス感染症が 2 回, クリプトコッカス髄膜炎, クリプトスポリジウム

Table 1 Clinical characteristics of patients

\begin{tabular}{|c|c|c|c|c|c|c|c|c|c|c|}
\hline No & Case & Sex & Age & Risk factor & 1st. Ad. & Cause of AIDS diagnosis & WBC & $\mathrm{CD} 4$ & $\mathrm{CD} 4 / 8$ & Outcome \\
\hline 1 & K. T. & M & 18 & Hemophilia A & '88. 03.28 . & HIV wasting syndrome & 800 & 3.4 & 0.02 & Death \\
\hline 2 & M. M. & M & 37 & Homosexual & '88.07.01. & P. carinii pneumonia & 11,800 & 16.5 & 0.03 & Unknown \\
\hline 3 & K. K. & M & 24 & Hemophilia A & '88.08.18. & P. carinii pneumonia & UN & UN & UN & Death \\
\hline 4 & O. Y. & M & 21 & Hemophilia A & '90.05.22. & (ARC) & & & & Survived \\
\hline 5 & C.T. & M & 37 & Hemophilia B & '90.08.31. & HIV dementia & 4,500 & 219.7 & 0.16 & Death \\
\hline 6 & M. T. & M & 21 & Hemophilia A & '90.10.18. & P. carinii pneumonia & 4,900 & 82.8 & 0.28 & Survived \\
\hline 7 & F.A. & M & 31 & Hemophilia A & '90.12.05. & P. carinii pneumonia & 6,500 & 45.8 & 0.54 & Death \\
\hline 8 & K. S. & M & 27 & Hemophilia A & '91.09.17. & HIV dementia & 1,000 & 14.9 & 0.04 & Death \\
\hline 9 & S. T. & M & 19 & Hemophilia B & '92.06.16. & $(\mathrm{ARC})$ & & & & Survived \\
\hline 10 & T. Y. & M & 28 & Heterosexual & '93.01.06. & P. carinii pneumonia & 6,500 & 64.3 & 0.27 & Unknown \\
\hline 11 & K. E. & M & 70 & Heterosexual & '93.03.16. & Non-Hodgkin's lymphoma & 5,600 & 59.7 & 0.08 & Death \\
\hline 12 & Y.S. & M & 30 & Bisexual & '93.06.09. & Cryptococcus meningitis & 8,000 & 197.0 & 0.26 & Survived \\
\hline 13 & U. K. & M & 26 & Homosexual & '93.12.05. & Cytomegalo. retinitis & 4,400 & 23.3 & 0.04 & Survived \\
\hline
\end{tabular}


Table 2 Autopsy findings

\begin{tabular}{|c|c|c|c|c|}
\hline No & Patients & Brain & Lung & Other findings \\
\hline 8 & $\begin{array}{l}\text { K. S. 28y.o. } \\
\text { '92.12.17. Died }\end{array}$ & $\begin{array}{l}1,290 \mathrm{~g} \\
\text { HIV encephalopathy mono- } \\
\text { nuclear cell involvement } \\
\text { around the bulb }\end{array}$ & $\begin{array}{l}\text { bilateral pneumonia with } \\
\text { pulmonary haemorrhage, } \\
\text { bronchitis }\end{array}$ & Cytomegalovirus infection (ileum) \\
\hline 11 & $\begin{array}{l}\text { K. E. 70y.o. } \\
\text { 93. 4.14. Died }\end{array}$ & nothing particular & $\begin{array}{l}\text { malignant lymphoma in } 1 \text { t. } \\
\text { lower lobe direct invasion } \\
\text { to pleura and hilus } \\
\text { organized pneumonia with } \\
P \text {. carinii }\end{array}$ & $\begin{array}{l}\text { Cytomegalovirus infection (adrenal gl) } \\
\text { molluscum contagiosum (pox virus inf.) } \\
\text { condyloma acuminatum (papilloma virus) }\end{array}$ \\
\hline 5 & $\begin{array}{l}\text { C. T. 39y.o. } \\
93.6 .5 \text {. Died }\end{array}$ & $\begin{array}{l}1,550 \mathrm{~g} \\
\text { markedly brain atrophy } \\
\text { multiple glial nodules in } \\
\text { cerebral cortex }\end{array}$ & $\begin{array}{l}\text { Cytomegalovirus pneumo- } \\
\text { nitis }\end{array}$ & $\begin{array}{l}\text { Cytomegalovirus infection (esophagus, } \\
\text { adrenal gland) } \\
\text { condyloma acuminatum (papilloma virus) }\end{array}$ \\
\hline 7 & $\begin{array}{l}\text { F.A. 34y.o. } \\
94.3 .17 . \text { Died }\end{array}$ & $\begin{array}{l}1,200 \mathrm{~g} \\
\text { markedly brain atrophy }\end{array}$ & $\begin{array}{l}\text { bilateral pneumonia with } \\
\text { pulmonary haemorrhage } \\
\text { pulmonary hypertension }\end{array}$ & $\begin{array}{l}\text { Cytomegalovirus infection (ileum, adrenal } \\
\text { gland) }\end{array}$ \\
\hline
\end{tabular}

Fig. 1 Survival duration of AIDS patients

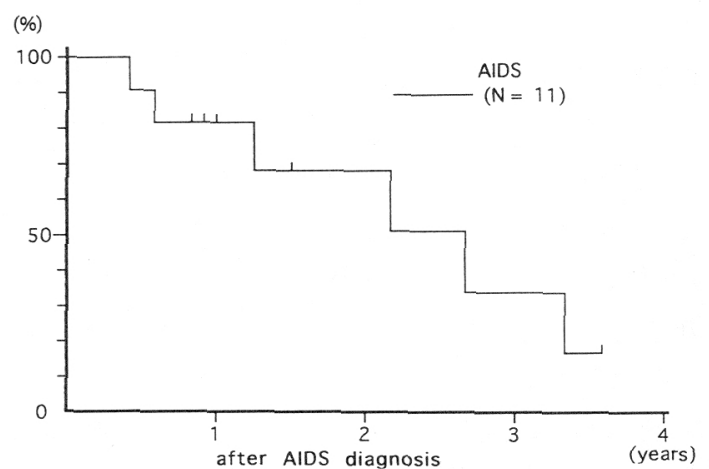

症, サイトメガロウイルス感染症が各 1 回で, 他 は原因不明であった。 HIV 脳症での3 回の入院 は，錯乱，意欲低下などを主訴としていた。その 他の 3 回は，骨折，急性胃粘膜病変，悪性リンパ 腫であった。

4）剖検所見（Table 2)

死亡例の, 死亡直前のCD4陽性リンパ球数は, 1.9〜 $13.6 / \mu \mathrm{I}$ (平均6.1/ $\mu \mathrm{I}$ ) であり，全例とも高 度に細胞性免疫能の低下をきたしていた。剖検は 4 例で施行された。脳では, 発症後経過の短かっ た悪性リンパ腫症例を除く 3 例で，大脳皮質の萎 縮，グリア結節形成，リンパ球・マクロファージ の浸潤など, HIV 脳症の特徵的な所見を得た。こ の3 例はいずれも死亡前に，高度の意欲低下を伴 う疾呆状態を呈していた。また，全例で肺炎，特 に細菌, 真菌の感染巣がみられた。皮虐所見では,
Fig. 2A Molluscum contagiosm showing hyperkeratosis with numerous intracytoplasmic inclusions. Inflammatory reaction was sparse. (hematoxylin-eosin stain $\times 40$ ).

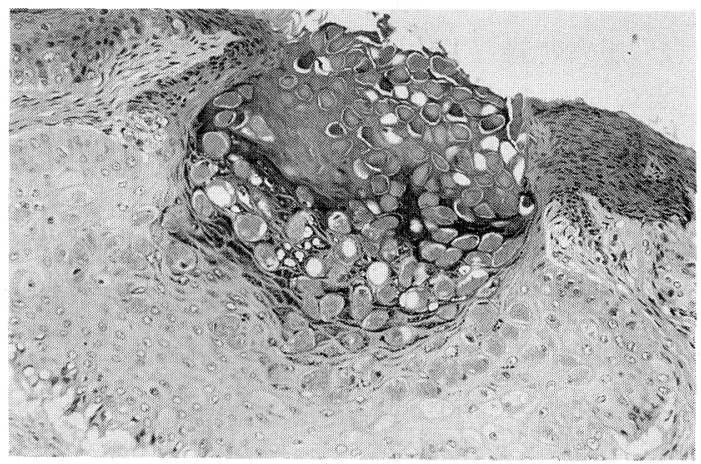

Fig. 2B Numerous condyloma acuminatum lesions on penis

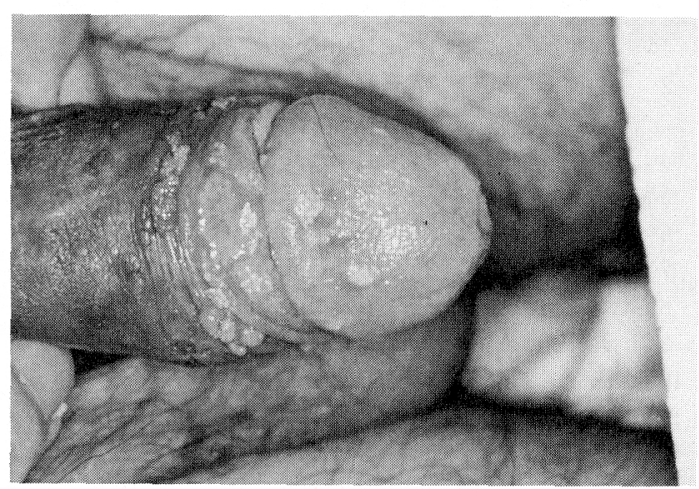


症例11で顔面, 頸部, 前胸部に汎発性の伝染性軟 属腫を認めたが, 組織学的には炎症反応に乏しく, リンパ球の浸潤はごく軽度であった（Fig. 2A)。 また尖圭コンジローマを, 症例11では陰茎に, 症 例 5 では陰茎, 陰囊, 肛門周囲に認めた（Fig. 2B). その他, 全剖検例で, サイトメガロウイルス 感染を示唆する巨細胞性封入体が, 副腎, 肺, 消 化管などの臓器に広範に認められた。

\section{考察}

わが国の HIV 陽性者は，血液製荗輸注により 感染した血友病患者がほとんどを占めるため, 大 多数が男性である。しかし近年，異性間性交渉に よる感染，あるいは HIV 陽性外国人就業女性の 報告例が急増しており，女性の HIV 陽性患者は 増加傾向にある。当科でも入院した HIV 陽性患 者は全例が男性であったが，外来での女性感染者 は増加傾向にあり, HIV 感染婦人の妊娠, 出産も 経験した。

当科に打ける AIDS 発症の診断根拠としては, カリ二肺炎が11例中 5 例を占めていたが，1991年 以降, 外来でペンタミジンの定期的吸入および $\mathrm{ST}$ 合剤の予防的投与を行い, カリ二肺炎の発症 は著しく減少した. 従来, CD4陽性リンパ球数が $200 / \mu 1$ 以下になると, カリ二肺炎が高率に発症す ると言われていたが7), 今日, ペンタミジンの定期 的吸入および ST 合風の予防的投与が十分に効果 をあげるようになり, カリ二肺炎の発症と CD4陽 性リンパ球数との相関はあまりなくなったように 思われる。

剖検は 4 例で行われ, 中枢神経病変, 皮膚病変, 悪性腫瘍, 多彩な日和見感染症など, AIDS に特徵 的な所見を得た. Navia らは, AIDS 患者70例を剖 検し, 中枢神経病変について, 臨床的に痴呆症状 のみられなかった症例では, 痴呆を呈した症例に 比べ, AIDS 罹患期間が短い傾向がみられたと述 べているが8), 本検討でも, 痴呆のみられなかった 1 例は, AIDS 罹患後急速な経過をとり, 5 カ月で 死亡した症例であった。また彼らは, AIDS の脳剖 検例では, 痴呆の有無に関わらずその $90 \%$ 以上で, グリア結節の形成, リンパ球・マクロファージの 浸潤, 白質の空胞変性などの所見がみられ, これ
らはHIVウイルスの直接感染による病変であ る, と報告しているが8), 本検討でも, 剖検した 4 例の内 3 例で同様の所見が得られた。皮膚病変で は 1 例で汎発性の伝染性軟属腫を，2例で尖圭コ ンジローマを認めた。伝染性軟属腫はポックスウ イルスの皮膚感染により起こる ${ }^{9)}$ HIV 感染者で の発生率は非感染者に比べ高く，5\%から $18 \%$ と 報告されており ${ }^{10) \sim 13)}, \mathrm{CD} 4$ 陽性リンパ球数が少な いものほど発生率が高く, 病変が広範に広がる傾 向がある ${ }^{14)}$.また HIV 感染者では組織学的に炎症 所見があまりみられないといわれており ${ }^{15)}$, 本症 例でも局所のリンパ球浸潤はほとんどみられず, 炎症所見に乏しかった。尖圭コンジローマは，七 トパピローマウイルスの皮膚感染により起こ る ${ }^{9)}$. HIV 感染者のなかでも同性愛者に多くみら れるといわれているが15)，本検討の 2 例は血液製 剤および異性間性交渉による HIV 感染者であっ た. HIV 感染者では, 病変が巨大化しやすく,ま た局所を切除しても再発しやすいことが知られて いる15).また, 全例でサイトメガロウイルス感染を 示唆する封入体が認められた。本感染症に関して は, 内外の AIDS 剖検報告例でもほぼ全例で認め られ，その内の $10 \%$ 前後は致命的となるとされて いる16). 現在, サイトメガロウイルスに対する治療 薬としては, ガンシクロビルのみが使用可能であ るが, 骨髄抑制などの副作用が強く,とくに AIDS 末期では十分な投与が難しいことが多い.今後は, カリニ肺炎と同様にサイトメガロウイルスに対す る予防, 治療法の確立が重要と思われる。

細胞性免疫不全の指標として一般的に用いられ ているものは，末梢血における CD4陽性リンパ球 数である.1993年に改訂された CDC の新分類で は, AIDS の診断基準に CD4陽性リンパ球数が $200 / \mu 1$ 以下という項目が加えられ ${ }^{17)}$ ，欧米では AIDS の診断例が一挙に増加した. 現在 CDC のこ の診断基準の妥当性については, 欧米で活発に議 論がなされており，わが国では採用を見合わせて いるのが現状である. 今回検討した入院例の AIDS 発症時のCD4陽性リンパ球数は, 3.4〜220/ 1 1 であったが, 10例中 8 例が, CD4陽性 リンパ球数 $100 / \mu 1$ 以下となるまで発症していな

平成 7 年 4 月 20 日 
かった。したがって，AIDS 診断のための CD4陽 性リンパ球数に関しては，検討の余地があるもの と思われる。

AIDS 発症後の生存期間に関しては，1991年に 厚生省 Natural History 委員会が97例を分析し, 血友病群で13.2力月, 非血友病群で8.9力月であっ たと報告している ${ }^{18)}$. 当科では, 少数例の検討だ が, AIDS 発症後の $50 \%$ 生存期間は 26 力で, 厚生 省の調査に比べ, 長期生存の傾向がみられた。現 在のところ, AIDS を発病すれば死は逃れられな いが，抗ウイルス薬の出現，日和見感染のコント ロール，症例の蓄積により，その予後は改善され つつある.すべての医療従事者は AIDSに対し て，より積極的な対応を求められている。

\section{文献}

1) Barre-Sinoussi, F., Chermann, J.C., Rey, F., et al.: Isolation of a $\mathrm{T}$-lymphotropic retrovirus from a patient at risk for acquired immune deficiency syndrome (AIDS). Science, $220: 868$ $-870,1983$.

2) Popovic, M., Sarngdharan, M.G., Read, E., et al.: Detection, Isolation and continuous production of cytopathic retroviruses (HTLV-III) from patients with AIDS and pre-AIDS. Science, 224 : 497-500, 1984.

3) Levy, J.A., Hoffmann, A.D., Kramer, S.M., et al.: Isolation of lymphocytopathic retroviruses from San Francisco patients with AIDS. Science, 225: 840-842, 1984.

4）苗村光廣：エイズ. 国民衛生の動向. 厚生の指標, $41: 158-161,1994$.

5）橋本修二，福富和夫，市川誠一，他：HIV 感染報 告の捕捉率およびAIDS 患者数の前回予測の評 価に関する検討. HIV 疫学研究班報告書, 23-27, 1994.

6）厚生省：サーベイランスのための AIDS 診断基 準。健医感発第14号，1988.

7) CDC: Guidelines for prophylaxis against Pneumocystis carinii pneumonia for persons infected with human immunodeficiency virus. Morbit. Mortal. Wkly Rep., 38(S-5) : 1-9, 1989.

8) Navia, B.A., Jordan, B.D. \& Price, R.W.: The
AIDS dementia complex. I, II. Ann. Neurol., 109 : 517-535, 1986.

9) Weedon, D.: Viral infections. In The Skin (third ed.) p. 677-700, Churchill Livingstone, Edinburgh, 1992.

10) Goodmann, D.S., Teplitz, E.D. \& Wishner, A.: Prevalence of cutaneous disease in patients with acquired immunodeficiency syndrome (AIDS) or AIDS-related complex. J. Am. Acad. Dermatol., 17 : 210-220, 1987.

11) Hira, S.K., Wadhawan, D. \& Kamanga, J. : Cutaneous manifestations of human immunodeficiency virus in Lusaka, Zanvia. J. Am. Acad. Dermatol., 19: 451-457, 1988.

12) Coldiron, B.M. \& Bergstresser, P.R.: Prevalence and clinical spectrum of skin disease in patients infected with human immunodeficiency virus. Arch. Dermatol., 125 : 357-361, 1989.

13) Matis, W.L., Triana, A. \& Shapiro, R.: Dermatologic findings associated with human immunodeficiency virus infection. J. Am. Acad. Dermatol., 17 : 746-751, 1987.

14) Schwartz, J.J. \& Myskowski, P.L.: Molluscum contagiosum in patients with human immunodeficiency virus infection. J. Am. Acad. Dermatol., 27 : 583-588, 1992.

15) Kaplan, M.H., Sadick, N., McNutt, N.S., Meltzer, M., Sarngadharan, M.G. \& Pahwa, S. : Dermatologic findings and manifestations of acquired immunodeficiency syndrome (AIDS). J. Am. Acad. Dermatol., 16: 485-506, 1987.

16) Jacobson, M.A. \& Mills, J.: Serious cytomegalovirus disease in the acquired immunodeficiency syndrome (AIDS). Ann. Intern. Med., 108 : 585, 1988.

17) CDC : 1993 Revised classification system for HIV infection and expanded surveillance case definition for AIDS among adolescents and adults. Morbit. Mortal. Wkly Rep., 41: 1-19, 1992.

18）三間屋純一，目黒 嵩，立波 忍，他：Natural History 委員会研究会報告. 厚生省「HIV 感染者 発症予防・治療に関する研究班」, 平成 2 年度報告 書, 9-16, 1991. 
Clinico-pathological Aspect of HIV-sero Positive Inpatients

Hiroyuki FUJITA, Takayoshi SOGA, Jyunichi SUZUKI, Yoshiaki ISHIGATSUBO, Hiroshi MOHRI \& Takao OKUBO

The First Department of Internal Medicine, Yokohama City University School of Medicine Youji NAGASHIMA \& Kazuaki MISUGI

The Second Department of Pathology, Yokohama City University School of Medicine

To describe the clinico-pathological aspect of HIV/AIDS inpatients, we reviewed HIV/AIDS inpatients in our hospital since 1988. We evaluated risk factors, CD4 counts, CD4/8 ratio, cause of death and the survival time after diagnosis of AIDS.

A total of 13 HIV sero-positive subjects were admitted to our hospital, including 11 cases (85\%) with AIDS. One patient was a foreigner. All cases were male; age range 18-70 years. Hemophiliacs and sexually transmitted patients account for $62 \%$ and $38 \%$ of cases, respectively. There were no cases of intravenous drug users. In all cases with AIDS, CD $4+$ cells and CD4/8 ratio significantly decreased with median value of $73 / \mu \mathrm{m}$ and 0.18 , respectively.

Six cases (54\%) were deceased and autopsy were done in four cases. Findings of autopsy revealed HIV encephalopathy and systemic various infeciton, including Pneumocystis carinii, cytomegalovirus, papilloma virus and pox virus. Cytomegalovirus infection was found in all cases; one had innumerable inclusion bodies in lung, adrenal gland and intestines. The median survival time after diagnosis of AIDS were 26 months. 